\title{
Menumbuhkan Jiwa Kreativitas Siswa Melalui Pembelajaran Berbasis IT Pada Era Pandemi Covid-19
}

\section{Isatul Hasanah}

IAIN Tulungagung

Corresponding Author $\otimes$ hasanahisatul@gmail.com

\begin{tabular}{|c|c|}
\hline & ABSTRACT \\
\hline $\begin{array}{c}\text { ARTICLE INFO } \\
\text { Article history: } \\
\text { Received } \\
01 \text { September } 2021 \\
\text { Revised } \\
10 \text { September } 2021 \\
\text { Accepted } \\
20 \text { September } 2021\end{array}$ & $\begin{array}{l}\text { Manusia tidak akan pernah bisa terlepas dengan teknologi. Hampir } \\
\text { semua aktivitas yang dilakukan oleh manusia berbasis teknologi. } \\
\text { Perkembangan teknologi membawa suatu perubahan bagi kehidupan } \\
\text { manusia. Salah satunya yaitu dalam bidang pendidikan. Tujuan dari } \\
\text { penelitian ini yaitu untuk mendeskripsikan terkait peran teknologi } \\
\text { dalam proses pembelajaran serta cara menumbuhkan jiwa kreativitas } \\
\text { siswa melalui pemanfaatan teknologi dalam proses pembelajaran. } \\
\text { Jenis penelitian ini yaitu penelitian kualitatif. Metode yang digunakan } \\
\text { yaitu metode kepustakaan (Library Research). Teknik pengumpulan } \\
\text { data yaitu dengan menggunakan sumber referensi dari buku, artikel, } \\
\text { serta jurnal yang relevan dengan penelitian tersebut. Analisis data } \\
\text { yang digunakan dalam penelitian ini yaitu dengan menggunakan } \\
\text { sajian data dan simpulan. Hasil kajian yang diperoleh oleh peneliti } \\
\text { yaitu secara garis besar teknologi mempunyai peran yang sangat } \\
\text { penting. Terutama dalam proses pembelajaran. Keberhasilan dalam } \\
\text { proses pembelajaraan saat ini dilihat dari maksimalnya seorang guru } \\
\text { dalam memanfaatkan teknologi yang dijadikan sebagai salah satu } \\
\text { strategi yang tepat. Penggunaan media tidak lain dapat menarik } \\
\text { perhatian siswa dalam proses pembelajaran. Meskipun pembelajaran } \\
\text { dilakukan secara virtual. Namun adanya teknologi tidak mengurangi } \\
\text { rasa ketertarikan siswa dalam mengikuti proses pembelajaran. Hal ini } \\
\text { disebabkan teknologi mampu memberikan suatu hal yang baru bagi } \\
\text { siswa. Terutama dalam hal memperoleh ilmu pengetahuan. Di sisi lain } \\
\text { pemanfaatan teknologi tidak hanya membantu siswa dalam } \\
\text { memaksimalkan proses pembelajaran melainkan dapat membantu } \\
\text { siswa dalam menumbuhkembangkan jiwa kekreativitasan yang } \\
\text { dimilikinya. }\end{array}$ \\
\hline Key Word & Kreativitas, Pembelajaran IT, Era Pandemi \\
\hline How to cite & $\begin{array}{l}\text { Isatul Hasanah, (2021). Menumbuhkan Jiwa Kreativitas Siswa Melalui } \\
\text { Pembelajaran Berbasis IT Pada Era Pandemi Covid-19 }\end{array}$ \\
\hline
\end{tabular}

\section{PENDAHULUAN}

Pandemi covid-19 melanda di seluruh dunia dan Indonesia termasuk di dalamnya. Semua negara berjuang melawan pandemi covid-19 dengan menerapkan kebijakan mulai dari lockdown, PSBB (pembatasan sosial berskala besar), sampai PPKM yang saat ini masih terus dilakukan. Hal tersebut bertujuan untuk meminimalisir banyaknya orang yang terpapar virus tersebut. Berbagai upaya yang telah dilakukan pada tahap PPKM (Pemberlakuan Pembatasan Kegiatan Masyarakat) ternyata membuahkan hasil. Yaitu media 
mengabarkan bahwa terdapat kasus penurunan terpaparnya virus covid-19 melalui adanya penerapan PPKM. Hal tersebut menjadi sebuah kabar kegembiraan bagi kalangan masyarakat terutama masyarakat Indonesia. Selain pemerintah menerapkan PPKM secara garis besar pemerintah juga melakukan strategi dalam mengurangi penambahan kasus covid-19. Salah satu strategi yang dilakukan oleh pemerintah yaitu mengajak warga negara untuk melakukan tahap vaksinasi (Hardy, 2020). Hal tersebut bertujuan untuk meningkatkan imunitas tubuh. Disebabkan kekebalan tubuh saat ini sangat diperlukan untuk meminimalisir tertularnya virus covid-19.

Dampak adanya pandemi covid-19 memberikan pengaruh yang cukup besar terutama dalam bidang pendidikan (Rosali, 2020). Sistem pembelajaran terpaksa dilakukan dengan sistem daring atau disebut dengan sistem online. Penerapan pembelajaran tersebut tidak hanya diberlakukan pada tingkat sekolah dasar saja, melainkan sampai pada perguruan tinggi. Berbagai keluhan disampaikan, baik dari siswa sendiri maupun kalangan orang tua. Salah satu contohnya yaitu orang tua sudah merasa jenuh dalam mendampingi anaknya mengikuti proses pembelajaran secara daring. Orang tua menginginkan untuk segera melakukan proses pembelajaran secara tatap muka. Meskipun dalam satu pekan hanya masuk beberapa hari saja. Namun pemerintah belum membolehkan mengadakan pembelajaran secara tatap muka sebelum semua para pendidik maupun siswa sudah divaksinasi. Keinginan hidup normal menjadi keinginan bersama terutama bagi kalangan siswa yang saat ini sangat menginginkan untuk belajar bersama temannya secara tatap muka langsung (Astini, 2020). Namun dalam melakukan pembelajaran secara langsung perlu memperhatikan beberapa hal. Terutama mematuhi protokol kesehatan agar tidak terjadi penambahan kasus baru.

Penerapan pembelajaran dengan sistem online memiliki nilai yang positif bagi seorang guru maupun siswa (Baety, D \& Munandar, D, 2021). Salah satunya yaitu seorang pendidik mampu berinovasi dalam menyampaikan materi pembelajaran dengan memanfaatkan segala jenis media yang ada. Hal tersebut tentu akan mengasah pengetahuan seorang guru dalam memperluas ilmu pengetahuannya. Terlebih kondisi saat ini seorang guru mempunyai banyak waktu dalam memperkaya ilmu pengetahuannya melalui adanya pemanfaatan teknologi. Sedangkan bagi siswa dapat membantu dalam memperoleh ilmu pengetahuan secara cepat dan mudah. Ilmu teknologi semakin hari semakin berkembang yang memungkinkan sistem pembelajaran yang ada di indonesia juga ikut berkembang (Hanifah Salsabila, Irna Sari, Haibati Lathif, Puji Lestari, \& Ayuning, 2020). Kualitas ilmu pengetahuan yang akan diperoleh oleh siswa juga tampak meningkat. Hal ini dapat dilihat dari 
proses pembelajaran yang dilakukan secara daring siswa tetap menunjukkan keaktifannnya melalui tugas yang diberikan oleh guru serta menjawab kuis ketika proses pembelajaran berlangsung. Pada satu sisi masyarakat mempunyai pandangan terkait pembelajaran yang dilakukan secara online. Mereka banyak berpendapat bahwa pembelajaran online membuat siswa merasa jenuh serta ilmu yang diperoleh oleh siswa tidak semaksimal ketika pembelajaran dilakukan secara tatap muka langsung. Padahal ketika kita mengamati proses pembelajaran tentu tidak semua siswa tidak dapat mencerna ilmu yang diberikan oleh guru melainkan siswa lebih mudah dalam mendapatkan ilmu pengetahuan.

Setiap proses pembelajaran yang dilakukan tentu mempunyai tujuan yang jelas. Hal ini disebabkan berkaitan dengan pengetahuan yang akan diperoleh oleh siswa. Seorang guru tak henti-hentinya berupaya melakukan perencanaan yang matang untuk memaksimalkan proses pembelajaran yang dilakukan secara daring. Mulai dari menyusun strategi yang tepat, memilih media yang sesuai serta jenis penilaian yang akan digunakan. Perlu diketahui bahwa pembelajaran yang dilakukan secara daring atau disebut sistem online membuka peluang bagi seseorang dalam meningkatkan ilmu kreativitasnya. Terutama bagi siswa. Akan tetapi dalam menumbuhkan jiwa kreativitas seseorang diperlukan adanya proses yang berawal dari dirinya sendirinya. Tumbuhnya jiwa kreativitas siswa dapat dilihat dari penemuan ide-ide yang baru (Rohmadani, 2020). Selama proses pembelajaran dilakukan secara luring tentu siswa hanya memperoleh ilmu pengetahuan melalui penjelasan guru tanpa mencari sumber lain yang ada di media sosial. Sehingga hal tersebut membuat jiwa kreativitas siswa sulit untuk dikembangkan. Padahal jiwa kreativitas itu sangat penting untuk dikembangkan guna untuk menciptakan sesuatu hal yang baru. Kondisi saat ini sangat tepat untuk menumbuhkan jiwa kreativitas yang dimiliki oleh siswa. Hal ini disebabkan pemanfaatan teknologi sangat membantu siswa dalam memperluas ilmu pengetahuannya.

Penggunaan teknologi dalam proses pembelajaran secara garis besar menjadi hal utama dalam melaksanakan proses pembelajaran (Pebria Dheni Purnasari, 2020). Hag dan Keen mengemukakan bahwa teknologi merupakan seperangkat alat yang dapat membantu atau mempermudah sebuah pekerjaan yang berhubungan dengan pemprosesan informasi. Dalam hal ini memanfaatkan teknologi selama pembelajaran daring sangat dibutuhkan agar pembelajaran tetap berlangsung. Namun teknologi tidak hanya berperan sebagai alat yang dapat membantu seorang guru dalam menyampaikan materi pembelajaran agar tercapai secara maksimal. Melainkan penggunaan teknologi juga dapat membantu peserta didik dalam menumbuhkan jiwa kreativitasnya. 
Terutama dalam hal proses pembelajaran. Oleh sebab itu kondisi pandemi covid-19 tidak hanya membuat siswa merasa dirugikan melainkan dapat memberikan nilai yang positif bagi siswa. Penelitian ini bertujuan untuk mendeskripsikan terkait peran teknologi dalam proses pembelajaran serta cara menumbuhkan jiwa kreativitas siswa melalui pemanfaatan teknologi dalam proses pembelajaran.

\section{METODE PENELITIAN}

Penelitian ini merupakan jenis penelitian kualitatif dengan metode kepustakaan (Library Research) artinya menggambarkan atau mendiskripsikan suatu data yang hasilkan melalui buku, artikel serta penelitian terdahulu yang relevan dengan permasalahan yang akan diteliti. Peneliti dalam penelitian ini tidak melakukan sebuah riset dilapangan melainkan hanya fokus pada sumbersumber kepustakaan yang ada. Data yang telah dikumpulkan kemudian dianalisis dengan menggunakan analisa deskriptif yakni dimulai dari pengumpulan data, menganalisis kebutuhan, merumuskan pokok-pokok bahasan yang akan dikaji dan ditarik kesimpulan. Teknik pengumpulan data dalam penelitian ini peneliti menggunakan menggunakan teknik yang sifatnya non interaktif yang berupa dokumen-dokumen. Sedangkan teknik analisis data dalam penelitian ini peneliti menggunakan reduksi data dan sajian data.

\section{HASIL DAN PEMBAHASAN}

Pendidikan sejatinya mampu dimaknai sebagai sebuah proses sosial yang terus bergerak secara dinamis mengikuti perkembangan zaman (Afifatu Rohmawati, 2015). Seperti halnya kondisi saat ini yang tidak mengharuskan pembelajaran dilakukan di dalam kelas yang didampingi oleh gurunya. Melainkan pembelajaran dapat dilakukan di rumah dengan baik. Adanya perubahan sistem pembelajaran bukan berarti siswa tidak membutuhkan seorang guru. Disebabkan posisi seorang guru tidak dapat tergantikan oleh apapun. Meskpun saat ini teknologi merajelela dalam dunia pendidikan. Akan tetapi guru adalah ujung tombak yang dapat mengantarkan peserta didik menuju keberhasilannya.

Keberadaan seorang guru yang berkompeten dan professional dalam bidangnya merupakan salah satu syarat yang wajib dipenuhi untuk meningkatkan kualitas pembelajaran. Hal ini senada dengan pendapat yang dikemukakan oleh Anwar bahwa seorang guru dalam melaksanakan tugasnya harus memiliki kemampuan dan ketrampilan yang beranekaragam (Anwar, 2019). Hal ini bertujuan agar seorang guru dapat menyesuaikan dengan 
keadaan serta mampu bersaing dengan negara lain dan tidak ketinggalan zaman.

Tujuan pendidikan yang ada di Indonesia saat ini adalah mencetak generasi muda yang mampu memiliki pengetahuan yang luas (Tutik Rachmawati dan Daryanto, 2015). Mengingat zaman sekarang disebut dengan zaman teknologi. Artinya semua orang tahu akan teknologi. Terutama bagi siswa harus memahami tentang manfaat teknologi dalam sebuah pembelajaran. Siswa harus mampu beradaptasi dengan beranekaragamnya sistem teknologi yang ada. Mengingat kemajuan teknologi merupakan salah satu perubahan yang dapat mengubah pola pikir manusia. Komunikasi dua arah tidak lagi menjadi acuan penilaian bahwa pembelajaran akan berkualitas (Ronaldo Mota David Scott, 2014). Karena semenjak pandemi merajalela pada selurub penjuru dunia sistem pembelajaranpun sering disebut dengan pembelajaran satu arah. Artinya lebih mengumatakan pada keaktifan siswa. Namun di sisi lain berkembangnya ilmu teknologi memiliki dampak positif maupun negatif. Ada banyak pendapat yang berkaitan dengan pemanfaatan teknologi dalam pendidikan. Nicholas Gane berpendapat bahwa teknologi internet dapat mengubah pola kehidupan sehari-hari, termasuk cara bekerja, akses dan pertukaran informasi, berbelanja, bertemu orang-orang, memelihara serta mengatur hubungan sosial yang ada (Cholik, 2017). Adanya internet memudahkan seseorang berkomunikasi tanpa dibatasi ruang dan waktu. Dengan adanya internet, seseorang juga dapat belajar atau menempuh pendidikan jarak jauh dengan mudah. Namun, tidak dapat dipungkiri bahwa hal ini dapat mengubah tatanan sosial di masyarakat, seperti dapat merubah seseorang menjadi lebih individualis dan apatis terhadap keadaan sekitar mereka.

Penggunaan teknologi pada era global saat ini bukan lagi merupakan hal yang baru. Termasuk pada dunia pendidikan (Helge, Kris, 2013). Dalam proses belajar mengajar teknologi sangat dibutuhkan. Terlebih saat ini sistem pembelajaran dibasiskan dalam sistem daring atau online. Sehingga sudah sewajarmya dalam proses pembelajaran melibatkan teknologi di dalamnya. Ilmu teknologi dalam dunia pendidikan sering disebut dengan teknologi pendidikan. Hal ini disebabkan teknologi pendidikan merupakan salah satu metode bersistem untuk merencanakan dan menilai dari seluruh kegiatan yang dilakukan manusia. Hal ini senada dengan pendapat Wartomo bahwa teknologi pendidikan merupakan proses yang sistematik dalam membantu memecahkan masalah pembelajaran (Wartomo, 2018). Terutama sistem pembelajaran yang dilakukan saat ini banyak sekali problem yang harus diatasi oleh kalangan guru. Sehingga adanya pemanfaatan teknologi menjadikan salah 
satu solusi yang tepat dalam mengatasi masalah yang ada di dalam pembelajaran.

Teknologi di dalam perkembangannya, tentu membawa perubahan dalam kehidupan sehari-hari, termasuk perubahan di bidang pendidikan (Syaharuddin, 2020). Ada beberapa perdebatan terkait dengan penggunaan teknologi di dalam pendidikan. Pertama, teknologi dapat meningkatkan pembelajaran. Artinya pembelajaran yang dilakukan tidak monoton atau konvensional. Melainkan di dalamnya melibatkan sebuah teknologi dengan cara merancang media atau strategi yang lebih tepat. Hal tersebut bertujuan untuk menarik perhatian siswa. Peneliti menganalisa dari beberapa jurnal bahwa hampir $85 \%$ siswa lebih tertarik dengan memanfaatkan teknologi dalam proses pembelajaran. Hal ini disebabkan terknologi mempunyai peran yang cukup penting dalam menumbuhkan semangat siswa. Terlebih kondisi pembelajaran saat ini dilakukan dengan sistem jarak jauh. Adapun perubahan bukan hanya terjadi pada bidang pendidikan. Melainkan pada aspek kesehatan, sosial, ekonomi, dan keuangan. Adapun gambar terkait perubahan yang dialami pada bidang tersebut dapat disajikan sebagai berikut.

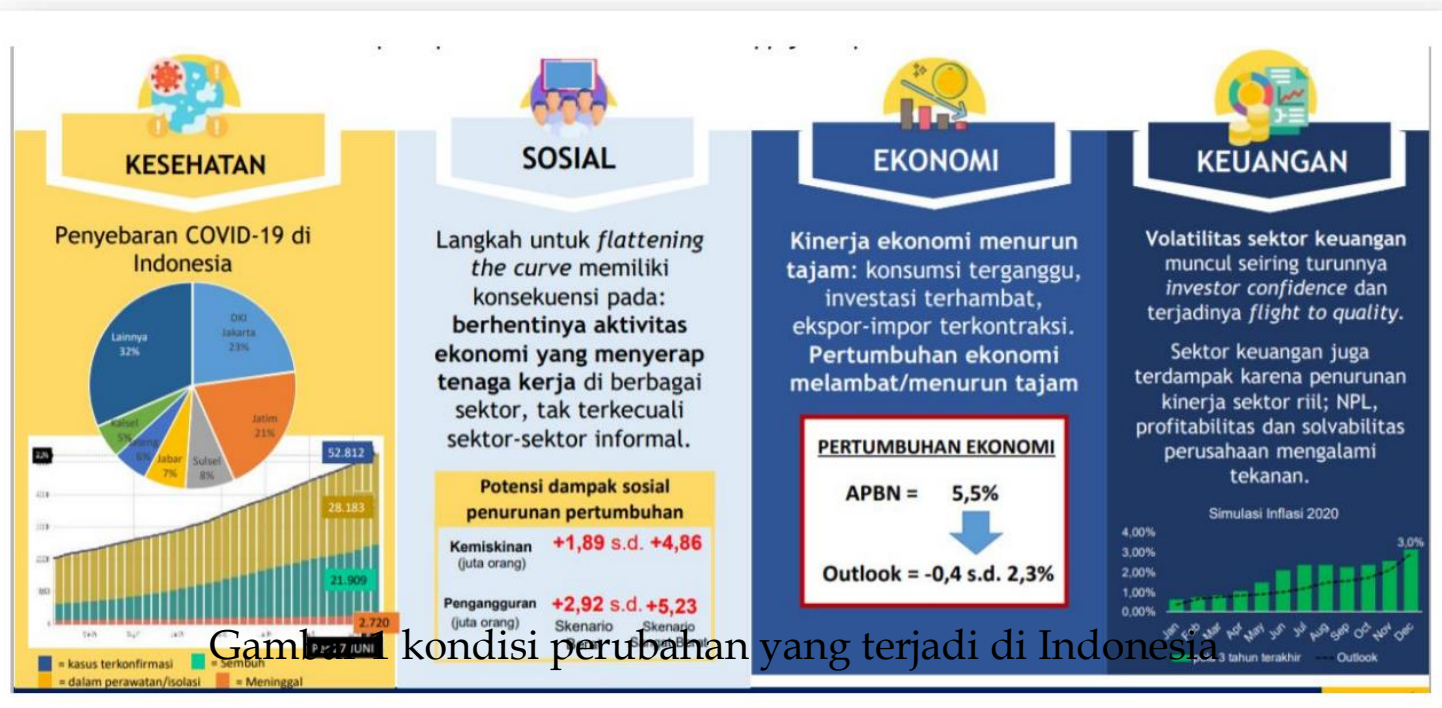

Berdasarkan gambar di atas dapat kita lihat bahwa perubahan yang terjadi di Indonesia semakin hari semakin meningkat. Baik terjadi dalam bidang kesehatan, sosial, ekonomi, dan keuangan. Hal ini tentu akan berakibat pada kemajuan teknologi yang dimanfaatkan oleh manusia. Terutama dalam bidang pendidikanpun juga akan mengalami peningkatan. Hal tersebut tentu dipengaruhi dengan adanya peran teknologi yang tidak dapat dipisahkan oleh kehidupan manusia. Mengingat semua aktivitas yang dilakukan oleh manusia di dalamnya melibatkan teknologi. 
Perubahan yang terjadi secara cepat membutuhkan transformasi pendidikan untuk menjawab kebutuhan manusia pada era global (Mohammed Ali Berawi, 2020). Hal ini bertujuan untuk membangun kreativitas serta potensi yang dimiliki oleh manusia. Di era digital saat ini tidak ada yang tidak mengenal teknologi. Hampir siswa sekolah dasar saat ini sangat aktif sekali dalam memainkan teknologi. Baik digunakan dalam proses pembelajaran maupun untuk menghibur diri yaitu untuk bermain game. Perubahan pembelajaran yang terjadi di Indonesia secara tidak langsung mengasah potensi yang dimiliki oleh siswa (Wayang Cong Sujana, 2019). Seperti halnya saat ini banyak kerajinan yang di buat oleh siswa untuk memenuhi tugas yang diberikan oleh guru. Seperti halnya seorang guru memberikan tugas untuk membuat kerajinan dari barang-barang bekas. Adanya kemajuan dalam bidang teknologi tentu dapat dimanfaatkan oleh siswa dalam mengembangkan kreativitas yang dimiliki oleh siswa (Helge, Kris, 2013). Hal tersebut juga merupakan salah satu peran teknologi dalam menstransformasi pendidikan agar lebih baik.

Teknologi dinilai sebagai alat yang dapat mengaktifkan siswa dalam mengasah kemampuan yang disesuaikan dengan perubahan zaman. Pendidikan telah bermetamorfosis menjadi lebih fleksibel yang berpusat pada siswa (Ronaldo Mota David Scott, 2014). Artinya sistem pendidikan mampu mengadaptasi perubahan sesuai kebutuhan masyarakat. Tentu hal tersebut mempunyai dampak yang luas terhadap pengguna teknologi. Dalam bidang pendidikan pemanfaatan teknologi dapat merubah pola belajar menjadi lebih efektif. Sejalan dengan perkembangan zaman pencapaian dalam belajar perlu mengalami transformasi. Pendidik harus mampu mengekspolarasi dari berbagai potensi yang dimiliki untuk mencapai tujuan yang maksimal. Pendidikan yang berkualitas sangat dibutuhkan. Terlebih Akhir-akhir ini pembelajaran digital banyak mendapat sorotan dan pembahasan dalam berbagai forum sebagai modus pendidikan yang potensial untuk membuat terobosan menghadapi pergeseran paradigma pendidikan sesuai dengan era digital (Syaharuddin, 2020). Sebagaimana dijelaskan bahwa dampak adanya pemanfaatan teknologi secara substansial mempengaruhi komponen pendukung pendidikan. Misalnya munculnya beragam bentuk bahan ajar yang berbasis elektronik, serta berbagai media yang dapat digunakan sesuai dengan kebutuhan.

Penggunaan teknologi dalam proses pembelajaran sangatlah bervariasi (Lindawati \& Rahman, 2020). Perlu diketahui awalnya teknologi digunakan hanya sebagai pengantar informasi. Yaitu melalui media sosial yang sangat cepat penyampaiannya. Namun saat ini teknologi dapat dijadikan sebuah 
metode, maupun faktor yang dapat mendukung dalam menumbuhkan jiwa kreativitas siswa. Dalam kegiatan proses belajar mengajar peran pendidik sangatlah penting. Terutama dalam hal mengembangkan jiwa kreativitas yang dimiliki oleh siswa. Zaman saat ini dikenal dengan zaman yang cepat akan suatu perubahan (W, Poluakan, Dikayuana, Wibowo, \& Raharjo, 2020). Terutama dalam hal memunculkan kreativitas yang nantinya akan berdampak pada kesuksesan di masa yang akan datang.

Jiwa kreativitas yang dimiliki oleh anak tentu berbeda-beda. Dengan demikian melalui pendidikan anak dapat mengembangkan jiwa kreativitasnya sesuai dengan kemampuan yang dimilikinya. Pendidikan kreativitas anak sejatinya bertujuan untuk membekali dalam menghadapi perkembangan zaman (Sunarto, 2018). Kreativitas anak didik dapat ditumbuh kembangkan melalui proses pembelajaran yang dilandasi oleh kemampuan dalam mengelola proses belajar. Seperti halnya memberikan kebebasan terhadap peserta didik. Robinson mengemukakan bahwa terdapat 3 karakteristik kreativitas yaitu meliputi imagination, purpose dan originality.

Kreativitas bermula dari berpikir dalam tataran gagasan yang mempunyai tujuan tertentu. Seperti halnya mampu memecahkan masalah serta menemukan hal yang baru (Dzulfiqar Restu Afghani., 2020). Pada kondisi pandemi saat ini seorang guru memberikan tugas kepada peserta didik dengan mengaitkan sebuah ketrampilan di dalamnya. Salah satu contohnya yaitu seorang pendidik mengajak siswa dan siswinya untuk berkreasi membuat masker berbahan kain. Tentu siswa dalam memilih kain tidak sama. Apalagi seorang guru memberikan penjelasan kepada peserta didik dengan memberikan penilaian yang baik untuk pembuatan masker yang unik. Siswa tentunya berlombalomba untuk mendesain pembuatan masker tersebut sekreatif mungkin. Mulai dari memilih warna kain, serta jenis variasi yang akan digunakan. Hal tersebut secara tidak langsung mengasah jiwa kekreativitasan siswa melalui sebuah ketrampilan. Perlu diketahui Hal tersebut tidak hanya menguntungkan siswa saja melainkan juga kepada guru. Menumbuh kembangkan jiwa kekreativitasan seseorang tentu diperlukan adanya suatu proses secara bertahap (Murdiana, Jumri, \& Damara, 2020). Sehingga dalam hal ini seorang guru harus mampu menumbuhkan jiwa kekreativitasan anak tidak hanya cukup pada satu aspek melainkan pada aspek yang lainnya.

Pandemi covid-19 yang dikabarkan melalui media sosial yaitu secara tidak langsung akan membuahkan hasil. Apabila selalu mematuhi protokol kesehatan (Hasma, Musfirah, \& Rusmalawati, 2021). Hal ini juga menjadi salah satu cara untuk menumbuhkan jiwa kreativitas anak. Yaitu seorang guru dapat mengajak siswa untuk membuat sebuah poster yang unik. Poster yang dibuat 
oleh siswa berupa ajakan untuk masyarakat akan pentingnya menjaga kesehatan. Terutama pada kondisi pandemi saat ini. Kesadaran masyarakat sangat membantu para protokol kesehatan dalam mengatasi pandemi covid-19. Mengingat teknologi saat ini sangat berkembang secara pesat. Hal tersebut dapat dimanfaatkan oleh siswa untuk menyebarluaskan poster yang telah dibuat melalui media sosial. Mengingat siswa tidak asing lagi dalam menggunakan teknologi, sehingga hal tersebut menjadi suatu hal yang sangat mudah bagi siswa. Terlebih saat ini siswa sangat aktif dalam menggunakan teknologi. Teknologipun membuat siswa menjadi lebih kreatif (Astini, 2020). Salah satu contohnya yaitu dalam mendesain sebuah karya yang dihasilkan oleh siswa. Seperti membuat mozaik, pot bunga yang memanfaatkan bahanbahan alam dan barang bekas. Jika siswa hanya terpacu pada pengetahuan yang dimiliki sebelumnya, tentu karya yang akan dihasilkan terlihat biasa-biasa saja. Namun saat ini siswa tidak hanya terpacu pada pengetahuan yang dimilikinya. Melainkan mengkolaborasi ide yang dimiliki dengan hasil temuannya. Sehingga hal tersebut dapat menciptakan suatu hal yang baru bagi peserta didik.

\section{KESIMPULAN}

Ilmu pengetahuan dan teknologi akan terus berkembang sesuai dengan perkembangan zaman. Hal ini tidak dapat dihindari. Disebabkan manusia membutuhkan teknologi. Pembelajaran saat ini mengalami sebuah perubahan yang menuntut pelaku pendidikan yaitu seorang guru dan siswa harus paham dan melek akan teknologi. Tentu hal tersebut berdampak pada diri masingmasing individu. Salah satunya yaitu seorang guru dapat mengasah ilmu pengetahuannya agar lebih berfikir secara luas. Sedangkan bagi siswa dapat memberikan suatu hal yang baru yang tentunya belum diketahui oleh siswa sebelumnya. Pemanfaatan teknologi dalam proses pembelajaran tidak sama sekali mengurangi nilai dari pentingnya ilmu pengetahuan. Melainkan membantu siswa dalam memecahkan sebuah persoalan dan mampu meningkatkan jiwa kreativitas yang dimiliki oleh siswa sebelumnya. Menumbuhkan jiwa kreativitas sangat penting untuk dikembangkan.

Disebabkan hal tersebut menjadi salah satu faktor pendukung dalam memunculkan ide-ide yang baru. 


\section{DAFTAR RUJUKAN}

Afifatu Rohmawati. (2015). Efektivitas Pembelajaran. Jurnal Pendidikan Usia Dini, 9(1), 2015. https://doi.org/https://doi.org/10.21009/JPUD.091

Anwar, B. (2019). Kompetensi Pedagogik sebagai Agen Pembelajaran. Shaut Al Arabiyyah. https://doi.org/10.24252/saa.v6i2.7129

Astini, N. K. S. (2020). Pemanfaatan Teknologi Informasi dalam Pembelajaran Tingkat Sekolah Dasar pada Masa Pandemi Covid-19. Jurnal Lembaga Penjaminan Mutu STKIP Agama Hindu Amlapura.

Baety, D, N., \& Munandar, D, R. (2021). Analisis Efektifitas Pembelajaran Daring Dalam Menghadapi Wabah Pandemi Covid-19. EDUKATIF: Jurnal Ilmu Pendidikan.

Cholik, C. A. (2017). Pemanfaatan Teknologi Informasi dan Komunikasi untuk Meningkatkan Pendidikan di Indonesia. Syntax Literate: Jurnal Ilmiah Indonesia.

Dzulfiqar Restu Afghani., S. (2020). Kreativitas Pembelajaran Daring untuk Pelajar Sekolah Menengah dalam Pandemi Covid-19. Journal of Informatics and Vocational Education (JOIVE), 3(2).

Hanifah Salsabila, U., Irna Sari, L., Haibati Lathif, K., Puji Lestari, A., \& Ayuning, A. (2020). Peran Teknologi Dalam Pembelajaran Di Masa Pandemi Covid-19. Al-Mutharahah: Jurnal Penelitian Dan Kajian Sosial Keagamaan. https://doi.org/10.46781/al-mutharahah.v17i2.138

Hardy, F. R. (2020). Herd Immunity Tantangan New Normal Era Pandemi Covid-19. Jurnal Ilmiah Kesehatan Masyarakat.

Hasma, H., Musfirah, M., \& Rusmalawati, R. (2021). Penerapan Kebijakan Protokol Kesehatan dalam Pencegahan Covid-19. Jurnal Ilmiah Kesehatan Sandi Husada. https:// doi.org/10.35816/jiskh.v10i2.620

Helge, Kris, D. (2013). The Teaching Librarian: Web 2.0, Technology, and Legal Aspect. 31st October.

Lindawati, Y. I., \& Rahman, C. A. (2020). Adaptasi Guru Dalam Implementasi Pembelajaran Daring Di Era Pandemi Covid-19. Prosiding Seminar Nasional Pendidikan FKIP.

Mohammed Ali Berawi. (2020). Accelerating Sustainable Energy Development Through Industry 4.0 Technologies. International Journal of Technology, 11(8).

Murdiana, Jumri, R., \& Damara, B. E. P. (2020). Pengembangan kreativitas guru dalam pembelajaran kreatif. Jurnal Pendidikan Matematika Raflesia.

Pebria Dheni Purnasari. (2020). Pemanfaatan Teknologi Dalam Pembelajaran Sebagai Upaya Peningkatan Kompetesnsi Pedagogik. Jurnal Publikasi Pendidikan, 10(3), 189-196. 
Rohmadani, A. I. (2020). Dampak Covid 19 Terhadap Cara Berpikir Dalam Pembelajaran Daring: Studi Kasus di Yogyakarta. Edification Journal. https://doi.org/10.37092/ej.v3i1.224

Ronaldo Mota David Scott. (2014). Education for Innovation and Independent Learning. 5th February.

Rosali, E. S. (2020). Aktifitas Pembelajaran Daring Pada Masa Pandemi Covid 19 Di. Geography Science Education Journal (GEOSEE).

Sunarto. (2018). Pengembangan Kreativitas-Inovatif dalam Pendidikan Seni Melalui Pembelajaran Mukidi. Jurnal Refleksi Edukatika, 8(2), 107-113.

Syaharuddin. (2020). Menimbang Peran Teknologi dan Guru dalam Pembelajaran di Era COVID-19. Menimbang Peran Teknologi dan Guru Dalam Pembelajaran Di Era COVID-19.

Tutik Rachmawati dan Daryanto. (2015). Teori Belajar dan Proses Pembelajaran yang Mendidik. Yogyakarta: Gava Media.

W, R. W. A., Poluakan, M. V., Dikayuana, D., Wibowo, H., \& Raharjo, S. T. (2020). Potret Generasi Milenial Pada Era Revolusi Industri 4.0. Focus: Jurnal Pekerjaan Sosial. https://doi.org/10.24198/focus.v2i2.26241

Wartomo. (2018). Peranan Teknologi Pendidikan Terhadap Peningkatan Kualitas Sumber Daya Manusia. Elementary School.

Wayang Cong Sujana. (2019). Fungsi dan Tujuan Pendidikan Indonesia. Pendidikan Dasar, 2(3). Retrieved from http:/ / ejournal.ihdn.ac.id/index.php/AW 